\title{
DIGNIDADE DA PESSOA HUMANA E RESPONSABILIDADE CIVIL
}

\author{
OTHON DE AZEVEDO LOPES*
}

I- Considerações iniciais; II - Dignidade da pessoa humana, autonomia e responsabilidade; $I I .1$ - A dignidade humana em Kant; 11.2 - A dignidade da pessoa humana e a responsabilidade; III - Modelos de responsabilidade civil e dignidade da pessoa humana; III.I - O modelo de responsabilidade por ato ilícito e a dignidade da pessoa humana; III.1.1 - Breve histórico do modelo subjetivo de responsabilidade; III.1.2 - A culpabilidade e as sanções civis; III.2 - A teoria do risco e outros modelos de responsabilidade por eqüidade (objetiva); III.2.1 - As condições sociais para o surgimento e alargamento da teoria do risco; III.2.2 - O alargamento da responsabilidade; III.2.3 - Os modelos de responsabilidade por eqüidade (objetiva); III.2.4 $O$ modelo de responsabilidade por eqüidade com base no risco; 111.2 .4 .1 - Noção sobre o risco; III.2.4.2 - A teoria do risco e a dignidade da pessoa humana; IV - Considerações finais

\section{I- Considerações iniciais}

O novo Código Civil, ao iniciar sua parte geral, pela personalidade, capacidade e direitos de personalidade, deixou muito clara a relevância da dignidade da pessoa humana para o direito civil. Ao enunciar em seu artigo $1^{\circ}$ que toda pessoa é capaz de direito e deveres na ordem civil consagrou a pessoa humana como um sujeito de direito universal, positivando mais uma vez o desdobramento mais difundido de tal princípio nas democracias ocidentais.

No âmbito do direito constitucional, desde a Lei Fundamental de Bonn, tem sido tradição dos Estados Democráticos de Direito erigir a dignidade da pessoa humana como um dos seus fundamentos. Após a redemocratização em 1988, como

* Advogado, mestre em direito pela Universidade de Brasília, professor de responsabilidade civil e introdução ao direito na Faculdade de direito da Universidade de Brasília. 
não poderia deixar de ser, a Constituição brasileira em seu art. $1^{\circ}$, III, erigiu a dignidade da pessoa como um dos pilares da República Federativa do Brasil.

Todavia, a centralidade da dignidade da pessoa humana no direito civil não é um aporte do século XX. Não se pode esquecer que Kant, o principal teórico da dignidade da pessoa humana, teve influência decisiva sobre a escola histórica do direito e seu desdobramento pandectista ${ }^{1}$. Por sua vez, em razão de sua abstração e comunicabilidade, os conceitos desenvolvidos por essa última escola, capitaneada por Windscheid, tiveram marcante influência na ciência do direito civil, bem como em todos os Códigos Civis Ocidentais promulgados após o Código Civil alemão o BGB de 1896.

No novo Código Civil de 2002, a influência de tal escola germânica pode ser dimensionada pelo marcante destaque dado a uma parte geral, inovação do BGB, assim como a abertura do Código com os direitos de personalidade, inovação do Código Civil suíço. Não menos relevante é. a estruturação do Código a partir de conceitos abstratos e científicos como os de pessoas, bens, atos, fatos, prescrição, decadência etc., o que mais uma vez demonstra a influência da escola histórica e de seu desdobramento pandectista.

Se os direitos de personalidade ocupam uma posição central no novo Código Civil de 2002, se a própria dignidade da pessoa é um dos princípios fundamentais do Estado Democrático de Direito Brasileiro e se a escola das Pandectas, de forte influência kantiana, forneceu a concepção e a estruturação básica desse mesmo Código, sem dúvida alguma, a dignidade da pessoa humana é um princípio central para a compreensão do próprio direito civil.

Então, a tarefa do presente trabalho que enfoca a responsabilidade civil resume-se a revelar, a partir da análise da tradição do direito civil, a relevância da dignidade da pessoa humana para a imposição da sanção indenizatória. Não se trata, de forma alguma, de uma reconstrução ou de uma releitura do direito civil. Muito ao contrário, cuida-se apenas de revelar a significância desse princípio que se encontra subjacente a diversos conceitos e regras seculares da responsabilidade. $O$ objetivo de tal evidenciação é possibilitar que a dignidade da pessoa humana não seja obscurecida por preocupações meramente utilitárias, coisificantes ou de outra ordem, bem como para que tal princípio possa ser enxergado como o vértice, que já é, da responsabilidade.

O caminho para atingir tal desiderato obviamente terá de partir da própria explicitação do princípio da dignidade da pessoa humana. Kant fornecerá o apoio para o primeiro passo. A reconstrução de sentido das lições kantianas para o direito contemporâneo no âmbito da responsabilidade será a segunda etapa. A análise dos principais modelos de responsabilidade positivados no atual Código Civil, a partir da dignidade da pessoa humana, comporá a última etapa.

1 É o que deixa bem claro o seguinte trecho de WIEACKER (1957, pp. 342-3): A ética social material do antigo direito racionalista que descansava sobre tradições da Antigüidade e da ldade Média, foi contestada pela Crítica da razão prática de Kant e seus Princípios da Metafísica dos Costumes e substituída por uma ética formal do dever e da liberdade, derivada da autonomia moral da personalidade. Nessa forma foi acolhida pela ciência pandectística (destacado). 


\section{II.1. - A dignidade humana em Kant}

Sem dúvida alguma, Kant foi um dos teóricos que deu maior consistência ao conceito de dignidade humana, mostrando-se até hoje como a principal referência para a abordagem do tema. Em Kant, o conceito de dignidade humana está ligado à idéia do homem como fim em sim mesmo e ao conceito ideal de reino de fins, no qual os fins de cada homem se conectariam.

O reino de fins em Kant seria um enlace sistemático entre pessoas razoáveis e racionais por regras morais compartilhadas. Esse encontro só seria possível quando todas essas pessoas se tratassem mutuamente como seres razoáveis e racionais, e, por isso, como fins em si mesmas. Daí que cada qual não persegue tão-somente seus fins pessoais, mas também dá valor ao aperfeiçoamento moral e à felicidade alheia. Dentro do reino de fins, todos os homens têm autonomia, pelas leis que edita e aceita que são recíproca e universalmente reconhecidas. ${ }^{2}$

Uma característica essencial do reino de fins é a pertinência do homem como seu membro. Essa condição é a personalidade moral, que se mostra dotada de dignidade, ou seja, de um valor sem equivalente e por isso absoluto. Kant assim define a dignidade:

No reino dos fins tudo tem um preço ou uma dignidade. O que tem um preço pode ser substituido por algo equivalente, enquanto que aquilo que é superior a qualquer preço, não admitindo nenhum equivalente, tem uma dignidade.

Aquilo que se relaciona às inclinações è às necessidades gerais do homem tem um preço de mercado;... mas aquilo que constitui a condição necessária pela qual alguma coisa possa ser um fim em si mesma, não tem um valor relativo, ou um preço, mas um valor intrínseco, que é a dignidade." ${ }^{3}$

2 RAWLS (1997, p. 227) elabora melhor o significa de reino (dominio) de fins em Kant: "pelo que quer dizer Kant com um todo de fins em enlace sistemático, também deveríamos ter em conta o seguinte parágrafo. Desse modo, como disse nele, o enlace sistemático característico de um domínio [reino] dos fins surge quando todas as pessoas razoáveis e racionais se tratam a si mesmas $e$ as demais como pessoas e, portanto, como fins em si mesmas. Pela segunda formulação. isso significa que cada qual não só persegue seus fins (permissiveis) pessoais dentro dos limites dos deveres de justiça (os direitos dos homens) mas também dá um valor significativo e apropriado aos fins obrigatórios ordenados pelos deveres da virtude. Esses deveres, para enunciá-los sumariamente, são promover a própria perfeição moral e natural e a felicidade alheia. Adicionalmente. cada qual tem o dever de respeitar os direitos de justiça, pois também isso é meritório e uma obrigação (não um dever) de virtude, conforme o explica Kant."

3 KANT (1980, p. 68). 
O homem como ser racional, que age segundo sua autonomia, não tem um preço, muito menos um equivalente. A condição humana é assim revestida de dignidade por ser um fim em si mesma e jamais um meio.

A dignidade humana está ligada à idéia de tratar todos os homens como um fim em si. Nas palavras de Kant, o imperativo prático seria o seguinte: aja de forma a tratar a humanidade, seja na sua pessoa ou na de outra, sempre como um fim em si e jamais como um meio ${ }^{4}$. De tal idéia, Kant tira várias conclusões:

A primeira é a de que o homem não pode ser coisificado, transformado em objeto, já que é necessariamente um fim em si mesmo. A pessoa humana é, por isso, indisponível até mesmo por ato próprio. ${ }^{5}$

A segunda é a circunstância de que a violação de direitos humanos reduz o homem a um meio, na medida em que o violador estará utilizando o ofendido como um meio para os seus objetivos. ${ }^{6}$

A terceira conseqüência é a de que não basta não atentar contra a pessoa humana, sendo indispensável transformá-la nos fins de todas as ações. A humanidade, como um fim em si mesma, deve ser promovida ${ }^{7}$

A quarta está no fato de que o fim natural de todos os homens é a felicidade. Daí que, por reconhecer o outro como um fim em si, cada homem deve tomar os fins e a felicidade do outro, na medida do possível, como os seus fins. ${ }^{8}$

Uma última consequiência, não menos importante, é a de considerar que a clignidade da pessoa humana é um princípio supremo limitador de todos os demais, já que para Kant adviria da razão pura e não da experiência. ${ }^{9}$

4 Idem. Ibidem. p. 62.

5 Idem. Ibidem. p. 61: Mas o homem não é uma coisa, também não é um objeto empregável ¿implesmente como meio, porque, em todas as suas ações, deve ser sempre considerado como um î̀m em si mesmo. Por conseqüência, não posso absolutamente dispor do homem na minha pessoa para mutilá-lo, danificá-lo ou matá-lo.

6 Idem. Ibidem. p. 62: Eis que em tal caso [atentado à liberdade e à propriedade] é claro que quem viola o direito do homem se propõe a servir-se da outra pessoa simplesmente como meio. sem ter presente que o outro, na sua qualidade de ser razoável, deve ser sempre considerado ao mesmo tempo como fim, em função de ser capaz de assumir-se como fim de sua própria ação.

7 Idem. Ibidem. p. 62: Em terceiro lugar, no que concerne o dever contingente meritório em si mesmo, não é suficiente que a ação não contradiga a humanidade na nossa pessoa como fim em si mesma, mas é indispensável que seja de acordo como essa. Na humanidade, estão presentes disposições a uma perfeição maior do que as advindas da natureza em razão da humanidade no nosso sujeito; descuidar pode ser compatível com a conservação da humanidade como fim em si mesma, mas não com a promoção desse fim.

8 Idem. Ibidem. p. 63: Em quarto lugar, no que concerne o dever meritório em face do outro, o fim natural de todos os homens é a sua felicidade. É certo que a humanidade poderia existir também no caso em que ninguém contribuísse a felicidade dos outros sem diminuí-la; ... De fato, já que o sujeito é um fim em si, necessariamente os seus fins serão, naquilo que possivel, também os meus fins para que representação possa produzir em mim o seu efeito.

9 KANT (1980: 63): Esse princípio da humanidade de cada ser racional em geral como fim em si mesmo (que é a suprema condição limitadora da liberdade de ação de cada homem, não tem origem empírica; antes de tudo pela sua universalidade, pois abarca todos os seres racionais em 
Sinteticamente, pode-se dizer que o cerne da dignidade da pessoa humana em Kant seria considerar o homem universalmente, em função de sua autonomia, como um fim em si mesmo e por isso como um valor sem equivalente e inapreciável. Então, os desdobramentos morais e sociais dessa idéia seriam: 1) a impossibilidade de se coisificar o homem, relativizando-o ou mensurando-o; 2) a indisponibilidade de tal condição; 3 ) a transformação do ser humano em meio quando seus direitos fundamentais são violados; 4) a necessidade de se promover a humanidade como um fim em si mesma; 5) a constituição de uma comunhão de fins para a promoção da felicidade de cada indivíduo; e 6) a afirmação da dignidade da pessoa humana como um princípio supremo.

\section{II.2 - A dignidade da pessoa humana e a responsabilidade}

A autonomia é uma idéia central na dignidade da pessoa humana. Não se pode. porém, esquecer que a autonomia exerce-se em sociedade. Por isso, a necessidade de um reino de fins em que todas as autonomias se conectam por edição individual de leis universalmente e reciprocamente válidas, de modo que cada um não persegue apenas os seus fins, mas ao de todos os outros. Só há verdadeira autonomia e, portanto, respeito da dignidade humana quando a ação individual leva em consideração todos os outros como fins em si mesmos.

Do contrário, os outros estarão sendo coisificados e haverá um uso indevido da autonomia em descompasso com a responsabilidade que lhe é inerente. Em outras palavras, o indivíduo é dotado de autonomia e, por isso, é capaz de conhecer seus deveres e de dirigir seu destino pela sua vontade, conformando a sua conduta a conteúdos objetivos de sentidos obrigatórios, respondendo pelos seus fracassos. Autonomia implica responsabilidade. ${ }^{10}$

Essa a razão pela qual o Estado não pode, quando afirma a dignidade da pessoa humana, desprezar a capacidade de auto direção da ação em face de um conteúdo de sentido obrigatório, devendo abrir amplo campo para o livre exercício da vontade e, ainda, considerar necessariamente a consciência para aplicação de sanções. $\mathrm{Na}$ terminologia kantiana, alguém só pode ser punido se for digno de punição" se tendo consciência de seus deveres impostos por uma ordem legítima, tenha-os descumprido voluntariamente. $O$ sancionamento sem conexão com a autonomia, na linguagem hobbesiana, não passa de mero ato hostil do Soberano ${ }^{12}$.

geral, no qual nenhuma experiência pode determinar qualquer coisa; depois, porque nesse princípio a humanidade é concebida não como um fim dos homens (subjetivo), mas sim como um fim objetivo que, independentemente dos fins que proponhamos, deve constituir, como lei, a condição limitadora suprema de todos os fins subjetivos, já que advém da razão pura.

10 Nesse sentido, RAWLS (2000, p. 77): O terceiro aspecto pelo qual os cidadãos são vistos como livres diz respeito a serem percebidos como capazes de assumir responsabilidade por seus objetivos, $e$ isso afeia a maneira de avaliar suas várias reivindicações.

11 KANT (1993, p. 176).

12 HOBBES (2002, p. 139). 
Daí que a autonomia ética mostre-se como a única idéia capaz de transformar o homem em pessoa, ou seja, em indivíduo capaz de dirigir sua vida segundo a consciência de seus deveres perante uma ordem externa a ele próprio. É esta autonomia ética que permite ao direito valer como organização social, não apenas pela força, mas por adesão voluntária de sujeitos de direito conscientes e autônomos. Somente a partir de tal concepção de autonomia ética é que se podem entender os deveres como conteúdos de sentido obrigatórios a membros de uma comunidade.

O direito como uma ordem idealizada, ou seja, de dever ser, só pode ser vinculante, caso se compreenda o homem a partir de uma idéia correlata, isto é, como pessoa responsável, dotada de autonomia ética. Nas palavras de Weizel, enquanto a coação converte o homem em mero objeto de uma influência física, faz dele uma coisa entre as coisas, a obrigatoriedade impōe-lhe a responsabilidade por uma ordem em sua vida dotada de sentido, fazendo dele o sujeito conformador de sua vida. ${ }^{13}$ Dever jurídico e pessoa responsável são, portanto, conceitos indissociáveis.

Então, se o direito não quer se transformar em uma ordem terrorista e hostil que vale e se impõe apenas pela força, precisa reconhecer o homem como responsável. Em outras palavras, se a ordem social não quer forçar apenas enquanto poder, mas obrigar enquanto direito, deve reconhecer o homem como dotado de autonomia ética. Logo, qualquer sanção só pode ser o resultado do descumprimento voluntário de um dever por um ser dotado de autonomia. É, assim que a dignidade da pessoa humana reconhece o homem a um só tempo como sujeito autônomo de direitos e de deveres, evitando a sua coisificação.

\section{III - Modelos de responsabilidade civil e dignidade da pessoa humana}

Após esse delineamento do conteúdo da dignidade da pessoa humana, já é possível adentrar nos modelos de responsabilidades positivados no direito brasileiro e relacioná-los com a dignidade da pessoa humana, o que será feito a partir do Código Civil de 2002. Na parte geral do Código, encontra-se a definição de ato ilícito no art. 186:

Art. 186. Aquele que, por ação ou omissão voluntária, negligência ou imprudência, violar direito e causar dano a outrem, ainda que exclusivamente moral, comete ato ilícito.

Embora o ato ilícito e, conseqüentemente, a responsabilidade subjetiva ainda ocupem posição de destaque na parte geral do Código Civil de 2002, o parágrafo único do artigo 927 de tal diploma legal erigiu a responsabilidade com base no risco, independentemente de culpa, como outra fonte de responsabilidade civil, ou seja, da obrigação de reparar o dano. 
O Código Civil positivou, assim, duas grandes vertentes de modelos de responsabilidade: o modelo por ato ilícito e os modelos comumente chamados de responsabilidade objetiva. Cada um deles caracteriza-se por ser uma trilha diferente na experiência jurídica da imputação da responsabilidade. São diferentes formas vivenciais de encarar a realidade em contraste com o ordenamento jurídico.

As origens e os efeitos de cada modelo mostram-se, sem dúvida alguma, completamente diferentes. Todavia, ambos têm em comum o fato de serem utilizados no Estado Democrático de Direito e, portanto, estarem submetidos ao conteúdo deontológico da dignidade da pessoa humana.

\section{III.I - O modelo de responsabilidade por ato ilícito e a dignidade da pessoa humana}

A responsabilidade com base no modelo subjetivo adotado pelo artigo 186 do Código Civil claramente centra o seu foco na ação. Em tal hipótese, define-se a responsabilidade a partir da análise da conduta. É dizer, elege-se uma interferência individual no mundo: a ação, que se diferencia de um mero processo causal/natural por se tratar de uma formulação de sentido cuja espinha dorsal é a vontade que a cria e lhe dá forma. Por isso, uma das tarefas primárias do direito orienta-se a compreender e valorar objetivamente a ação e a interpretar. $E$ isso o que ocorre no modelo subjetivo de responsabilidade em que se contrasta a ação como construção de sentido individual com o ordenamento jurídico como construção de sentido vinculante social.

Em tal modelo, é a partir da pré-compreensão da ação humana como uma manifestação de vontade que se atribui a alguém a responsabilidade pelo dano. Não é por casualidade que o Código, no artigo 186, refere-se à ação ou omissão voluntária, negligência ou imprudência na definição do ato ilícito.

\section{III.1.1 - Breve histórico do modelo subjetivo de responsabilidade}

O art. 186 do Novo Código Civil consolidou a positivação de forma de responsabilização tradicional. A sua origem está na tradição judaico-cristã, caracterizando-se a responsabilidade pela contrariedade consciente e voluntária de um ato a um dever contido em um mandamento. Foi a partir dessa concepção que, no período pós-clássico do direito romano, alterou-se o conteúdo semântico da palavra culpa para que ela adquirisse o significado de ausência de diligência no cumprimento de um dever ${ }^{14}$.

A codificação de Justiniano, ocorrida no período pós-clássico do direito romano, acolheu a Lei Aquília e diversos outros textos romanos sobre responsabilidade dentro desse ambiente de influência cristã. Não se pode esquecer que tal compilação, além

14 Texto de ROTONDI (1922, pp. 465 e seg.) contém um estudo pormenorizado da evolução da responsabilidade civil denominado Dalla lex Auilia all' art. 1151 Cod. Civ.: ricerche storico-dogmatiche. 
de ter-se dado no Império Romano do Oriente com forte influência helênica, teve lugar após a cristianização da civilização romana.

$\mathrm{Na}$ Idade Média, essa concepção foi assimilada pelo direito comum e pelo direito canônico dos delitos. Ambos estavam estruturados em uma responsabilização que pressupunha a não-observância voluntária de uma lei ou desídia no seu cumprimento, que eram o cerne do pecado. Esse era o pressuposto para uma pena como forma de purgar a culpa ou mesmo para que se pudesse condenar alguém a reparar o dano.

Na Idade Moderna, a concepção de pecado da Idade Média foi secularizada e sistematizada, de acordo com a razão abstrata de tal período. $O$ delito, ou ilícito, era uma modalidade de pecado moral ${ }^{15}$, sem sentido religioso, como vontade mal direcionada em face de leis sociais de conteúdo vinculante e obrigatório. Com Grócio, o ilícito penal distinguiu-se do civil, estando esse último ligado a um direito natural abstraio de obter reparação por todo o dano culposamente causado ${ }^{16}$. Já, o ilícito penal teria por objetivo retribuir uma má ação com um padecimento (uma pena), segundo limites de utilidade social ${ }^{17}$. Então, ainda que a responsabilidade penal e a civil houvessem-se separado, ambas tinham como pressuposto básico a valoração de um ato necessariamente culposo.

Nesse contexto, diversos autores jusnaturalistas racionais, como Pufendorf, Domai, Photier, etc., elaboraram o conceito de ato ilícito, delito ou quase delito. A partir de sedimentação de tais estudos, foi possível que as primeiras codificações jusnaturalistas como a da Prússia, a da Baviera, a da Áustria e da França dedicassem títulos ou capítulos específicos para o surgimento da obrigação de indenizar derivada da prática de ato doloso ou culposo.

A experiência de tais códigos foi base para o refinamento científico da escola das Pandectas, que tomou possível a formulação do Código Civil alemão $(B G B)$ e do Código Civil suíço. Esses diplomas legais destacaram-se por preocupações de cientificidade, ou seja, uma precisão científica de sua linguagem, valorizando a disciplina lógica, a precisão conceitual, a abstração e a validade formal para formar um sistema abrangente, em que as cláusulas gerais também tiveram forte destaque.

Essa longa história assinala que o ilícito referido é essencialmente a avaliação de uma conduta humana em contraste com uma ordem deontológica de sentido. Qualificar um ato como ilícito equivale a atestar seu insucesso perante um dever. As sanções decorrentes de um modelo por ato ilícito mostram-se como decorrência de um julgamento centrado na conduta humana referida a um ordenamento. Aí está a explicação e a raiz do entendimento da concepção mais comum e usual, dentro da doutrina do direito, de que o ilícito é o ato contrário ao direito ${ }^{18}$.

15 Em relação à responsabilidade, para Hobbes, o pecado era um gênero que abrangia os crimes. Pecado, não era apenas transgressão da lei, mas qualquer manifestação de desprezo pelo legislador. HOBBES (2002, p.214).

16 GRÓCIO (1925, p. 8).

17 GRÓCIO (1925, p. 59).

18 ESPÍNOLA (1939, p. 551). 
O ilícito pressupõe necessariamente um ato humano. A valoração de licitude só acontece em face de comportamentos, de condutas humanas. Não que os fatos em sentido estrito, acontecimentos naturais, sejam indiferentes ao direito, mas que não se julga conformidade de um fato com o direito, apenas tiram-se conseqüências de tais acontecimentos. $O$ juízo de licitude só pode ter lugar diante de um ato voluntário, ou mais especificamente de ação como acontecimento dirigido e orientado pela vontade. ${ }^{19}$ Portanto, o modelo de responsabilidade por ato ilícito exige a verificação da ação direcionável pela vontade em referência a deveres positivados numa ordem jurídica.

\section{III.1.2 - A culpabilidade e as sanções civis}

A ilicitude comporta a análise de culpabilidade, que ocorre pela ação do autor não ser como exige o direito, apesar de o autor ter podido realizá-la de acordo com a norma ${ }^{20}$. A culpabilidade é um juízo de reprovação a uma pessoa dotada de consciência e capacidade que concretamente poderia ter atuado: conforme o direito, mas não o fez. É por meio da culpabilidade que se analisa a conduta específica perante um conteúdo deontológico de sentido.

Embora tenha alguns pressupostos formais como a imputabilidade, a culpabilidade não está a eles adstrita, mas se destina sobretudo a contrastar o ato dotado de uma história e uma significância própria com o horizonte de sentidos de dever existentes no ordenamento jurídico. É o insucesso concreto perante uma ordem de sentido que toma alguém digno de pena na terminologia kantiana. A função da culpabilidade é conferir sentido social ao ato, emprestando-lhe um contexto deontológico.

Apesar de tradicionalmente, nas sanções civis - restitutivas —, quando se utiliza o modelo por ato ilícito, a indenização ser consequiência de um juízo de reprovação da resolução de vontade, ainda que imprudente ou negligente, a extensão da sanção é determinada exclusivamente pelo dano. Assim, mesmo no ilícito civil, em que o juízo de culpabilidade é mais frouxo, pois não se trata de punição, mas de ressarcimento do dano, a avaliação da culpabilidade é da essência do ilícito, embora a regra seja a de que a indenização não se gradua de acordo com a reprovação. Como já diziam os bizantinos, in lege Aquilia et levíssima culpa venit. Basta a existência de qualquer culpabilidade para que surja a obrigação de reparar o dano na sua inteireza.

A culpabilidade apresenta, portanto, um duplo aspecto ${ }^{21}$, como fundamento individualizador e delimitador da sanção. Ela é o fundamento personalizador da sanção, pressupondo para isso a imputabilidade (capacidade de culpabilidade), a consciência da ilicitude e a exigibilidade da conduta diversa. Várias legislações civis 
falam em capacidade de entendimento e manifestação de vontade ${ }^{22}$, destacando esse aspecto personalizador.

A segunda função da culpabilidade, em razão de sua graduabilidade, está em permitir dosar a sanção. Embora, no direito civil, essa função seja amenizada pela natureza de sanção ressarcitória, a culpabilidade também pode atuar na delimitação da sanção. Nesse sentido, apesar de, em regra, o ressarcimento guardar necessária correlação com o dano, a culpabilidade é usada para atenuar a indenização nos casos de evidente descompasso entre a culpa e o dano, sendo este último desproporcionalmente maior que primeira ${ }^{23}$. Uma das inovações do Código Civil de 2002, a exemplo do Código Civil suíço, foi a de em seu art. 945, parágrafo único, tomar a indenização graduável, retirando a equivalência da indenização com o dano, para correspondê-la à culpabilidade (gravidade da culpa) quando haja uma evidente desproporção entre a pequena reprovação e o grande montante do dano.

Também na esfera da culpabilidade, o critério da direção final é um elemento constitutivo permanente. Na formação da ação, trata-se da direção dos meios da ação segundo seus fins; na culpabilidade, cuida-se da direção dos impulsos que motivam a tomada de decisão. A primeira é uma questão técnica, enquanto que a segunda é um problema ético sobre o valor ou desvaler dos impulsos que são determinantes para a tomada de decisão. Na culpabilidade, a questão central é situar os fins dos impulsos em um conteúdo de sentido supraindividual ao qual a pessoa se subordina e está obrigada em seu modo de viver.

O conceito de culpabilidade assim como o de direito e o de justiça pressupõem a aceitação de um sentido transcendente e obrigatório da vida. O ser humano só pode ser livre ou culpável, diante do pressuposto de que tenha capacidade de se orientar conforme os critérios do correio, do devido, do justo, ou seja, diante de uma instância objetiva que lhe imponha deveres e parâmetros para o seu agir. O correto, o devido e o justo são a linha divisora entre a liberdade e culpabilidade. Naquilo em que seja possível claramente a fixação do que é devido e do que é correto, o homem será livre para orientar sua ação no cumprimento de seus deveres e culpável quando não o fizer.

A culpabilidade é, pois - diante da existência de condições de direcionar os impulsos para o sentido do dever - , não realizar o ato devido por impulsos desvaliosos. A vontade culpável é, por isso, vontade não-livre. Daí que o dever de se superar em um ato existencial e orientar sua resolução conforme o dever origina-se para o homem ali onde os impulsos ameaçam um deslize para o reprovável. A

22 É o caso do art. 2.046 do Código italiano e do $\$ 827$ do Código Civil alemão.

23 Sobre o assunto, é de se ressaltar que várias legislações abrem expressamente espaço para o juízo de culpabilidade na fixação da indenização. $O$ art. 43 do Código Suíço de Obrigações é claro nesse sentido. Do mesmo modo, o novo Código Civil brasileiro abre espaço para tal juízo quando haja nítida desproporção entre a culpa e o dano (art. 944, parágrafo único): Art. 944. A indenização não se mede pela gravidade da culpa, mas pela extensão do dano.

Parágrafo único. Se houver excessiva desproporção entre o ato e dano, poderá o juiz reduzir, equitativamente, a indenização. 
culpabilidade é a ausência de autodireção conforme o dever, consistente em um desvio para a realização de um ato desvalioso.

Dessa maneira, é por intermédio da culpabilidade que os modelos subjetivos densificam de forma mais concreta a dignidade da pessoa humana. Por meio de tal juízo, garante-se que alguém só será sancionado se consciente e capaz de livre manifestação de vontade, de modo a poder dirigir seus atos pela vontade. A culpabilidade permite ainda que por meio da retribuição da gravidade da culpa fixem-se limites para as sanções. A culpabilidade estabelece, portanto, um nexo entre a idéia do ser humano como alguém dotado de autonomia e, portanto, de capacidade de entendimento e livre manifestação de vontade e imposição jurídica de sanções.

\section{III.2 - A teoria do risco e outros modelos de responsabilidade por equidade (objetiva)}

O parágrafo único do art. 927 do Novo Código Civil não estabeleceu apenas o modelo de responsabilidade subjetiva como fonte da obrigação de indenizar, tendo adotado a teoria do risco como origem do dever de reparar o dano. Todavia, o alargamento das hipóteses de responsabilidade objetiva não ficou apenas em tal parágrafo único. Diversos outros artigos indicam que a responsabilização está além da própria conduta como por exemplo o art. 928, o art. 931 e o 932, entres outros.

Embora o direito romano já tivesse algumas hipóteses de responsabilidade indireta como o effusum et deictum e o positum et suspensum ${ }^{24}$, foram as transformações sociais contemporâneas à Revolução Industrial que impulsionaram a teoria jurídica a superar o ato ilícito como a única origem da obrigação de indenizar. Então, a compreensão das denominadas teorias objetivas de responsabilidade pressupõe a análise, histórica das condições sociais dessa transformação nos pressupostos de responsabilização civil.

\section{III.2.I - As condições sociais para o surgimento e alargamento da teoria do risco}

O século XIX foi marcado pelo pensamento positivo e pela consolidação de diversos sistemas, sejam de conhecimento ou de ação. O Estado e o capitalismo, como realidades complexas, ganharam maturidade no século XIX. O Estado moderno racional firmou-se como uma máquina burocrática, tão bem descrita por Weber ${ }^{25}$.

24 Os dois mais conhecidos quase-delitos eram o effusum et deictum e positum et suspensum. $\mathrm{O}$ primeiro consistia na obrigação que surgia ao morador (habitator) de responder pelos danos causados na derrama de um líquido (effusum) e no arremesso de um objeto sólido (delectum), independentemente de participação no delito. Não se exigia, como na Lei Aquília, ato próprio ou mesmo o nexo de causalidade imediato. $O$ segundo caracterizava-se pelo perigo de objetos suspensos ou agregados aos edifícios que poderiam causar danos aos transeuntes. Nesses dois casos, o habitator era responsável pelos danos causados pela queda, não se indagando se o ato fora praticado por ele. Sobre o assunto MOREIRA ALVES (2002, V. II, p. 28).

25 WEBER (2000, p. 517 e seg.). 
O capitalismo, por sua vez, assumiu inegável abrangência dominando não só sobre as relações econômicas, mas também em todos os aspectos da vida social ${ }^{26}$. Esse foi um período de concentração do poder econômico em cartéis e monopólios, com forte expansão das grandes corporações de capital.

De outro lado, criaram-se movimentos sociais no Ocidente com o objetivo de alargar o direito de voto, bem como para defesa dos interesses dos trabalhadores, o que denotou o surgimento de novos afores sociais. No Brasil, essa complexificação do cenário social pôde ser identificada claramente na Era Vargas, em que houve uma superação da economia agrícola de exportação.

Eram novas demandas sociais que ampliavam o universo de necessidades a serem satisfeitas pelo Estado. Foram necessários direitos que permitissem resgatar o homem da situação de massificação, automatização, espoliação e coisificação que lhe havia sido imposta pelos excessos do capitalismo. Era o surgimento dos então denominados direitos sociais e econômicos.

O Estado, para permitir a inserção dos trabalhadores e as classes desfavorecidas, modificou a ordem econômica, estabelecendo restrições à propriedade e criando direitos trabalhistas, previdenciários e educacionais ${ }^{27}$, como exemplificam historicamente a Constituição Mexicana de 1917, a de Weimar e a Constituição Brasileira de 1934.

Entretanto, além dos sistemas e novos atores que se desenvolveram no século $\mathrm{XIX}$, o próprio século XX criou outras necessidades e outros protagonistas sociais. A complexificação da abrangência dos direitos fundamentais foi um outro fenômeno que se acentuou após a segunda guerra, como reflexo do incremento de complexidade do cenário social. A Declaração Universal dos Direitos Humanos de 1948 foi o primeiro documento de uma série de vários outros ${ }^{28}$ que exigiriam do Estado e do próprio direito a resposta para essa nova realidade. As dimensões até então já assumidas pelo direito somaram-se outras como a cultural, a científica. a ambiental etc., em uma densificação das pretensões universalistas da regulação jurídica, que

26 SOUSA SANTOS (2001, p. 146).

27 O Professor Menelick de CARVALHO NETTO (2000, p. 241) com propriedade expõe as linhas básicas dessa fase do Estado de bem-estar social: ... O Estado subsume toda a dimensão do público e tem de prover os serviços inerentes aos direitos de segunda geração à sociedade, como saúde. educação, previdência, mediante os quais alicia clientelas. Com essa crescente complexificação da estrutura da sociedade, verificada após a $l^{a}$ Guerra Mundial, tem curso, no século XX, portanto. uma remodelação do Estado de Direito para o do Estado Social ou de Bem-Estar Social ", em que o direito é materializado e, precisamente em razão dessas exigências de materialização do direito. não somente o Estado tem sua seara de atuação extraordinariamente ampliada para abranger tarefas vinculadas a essas novas finalidades econômicas e sociais que, agora, the são atribuidas, mas o próprio ordenamento ganha um novo grau de complexidade.

28 Entre as quais pode-se citar: A convenção para a Prevenção e a Repressão do Crime de Genocídio - 1948; As Convenções de Genebra de 1949 sobre a Proteção das Vítimas de Conflitos Bélicos; A Convenção Européia de Direitos Humanos - 1950; Os Pactos Internacionais de Direitos Humanos de 1966; A Convenção Americana de Direitos Humanos - 1969; A Convenção Relativa à Proteção do Patrimônio Mundial, Cultural e Natural - 1972; A Carta Africana dos Direitos Humanos e dos Direitos dos Povos - 1981 . 
passou a abranger gerações futuras e mesmo sujeitos indeterminados. A Constituição Brasileira de 1988 inseriu-se claramente nessa última fase, positivando várias dimensões da dignidade da pessoa humana, reconhecendo vários novos direitos, tais como: educação, cultura, desporto, ciência, tecnologia, comunicação social e meio ambiente.

O cenário social do século $\mathrm{XX}$ firmou-se, portanto, como um palco de crescente complexificação, que obviamente teve profundas consequiências na responsabilidade como instituto jurídico. $\mathrm{O}$ modelo de responsabilidade subjetiva por ato ilícito que no século XIX havia predominado, tanto no direito civil como no penal, não se mostrava mais suficiente para responder a todos os problemas sociais. $\mathrm{O}$ direito civil já no próprio século XIX criou e continuou a desenvolver várias teorias, no século $\mathrm{XX}$, que passaram a ser conhecidas como objetivas, como a do risco, garantia, eficiência, etc. para solucionar adequadamente tais problemas sociais no âmbito da reparação civil.

\section{III.2.2 - O alargamento da responsabilidade}

Os precursores da denominada responsabilidade objetiva foram alguns autores da escola do direito natural e das gentes. Especialmente Thomasius que, diante dos danos causados por indivíduos sem discernimento, defendeu a idéia de direito natural de todas as pessoas à reparação dos danos, apenas resguardando a equidade entre as pessoas envolvidas, sem necessidade de procurar outras razões. Na concepção de tal autor, a ação de responsabilidade civil não se ligava mais às fontes romanas por meio do damnun iniuria ou qualquer outro ilícito, mas apenas à equidade. Os Códigos prussiano e austríaco do século XVIII positivaram essa responsabilidade dos incapazes defendida por Thomasius ${ }^{29}$.

No entanto, o grande passo para o desenvolvimento da teoria do risco foi dado em 1838. Uma lei extravagante sobre as estradas de ferro na Prússia claramente estabelecia um caso especial de responsabilidade sem culpa para diversas atividades perigosas como estradas de ferro, indústrias, minas, etc. Tal lei contrastava com veemência da centralidade da responsabilidade por culpa, estabelecida pela doutrina do direito comum e acolhida pelas codificações jusnaturalistas, embora houvesse alguns casos de responsabilidade indireta e por eqüidade em tais consolidações.

A doutrina alemã e austríaca então passou a produzir uma vasta literatura sobre $o$ assunto. Um dos primeiros estudos sobre o assunto foi o de Kari Binding ${ }^{30}$, penalista de renome que, em uma obra de teoria geral do direito, opôs a pena, sempre necessariamente ligada a um ilícito, à reparação que poderia ter origem em aconte-

29 O art. 930 do Novo Código Civil acolhe exatamente a hipótese de responsabilidade defendida por Thomasius, in verbis: "Art. 928. O incapaz responde pelos prejuizos que causar, se as pessoas por ele responsáveis não tiverem obrigação defazê-lo ou não dispuserem de meios suficientes. Parágrafo único. A indenização prevista neste artigo, que deverá ser equitativa, não terá lugar se privar do necessário o incapaz ou as pessoas que dele dependem."

30 MARTON (1938, p. 161). 
cimentos heterogêneos que nem sempre seriam ilícitos. Para Binding, nos casos em que a reparação estivesse ligada ao ilícito, este não seria o aspecto mais importante.

Binding, na primeira edição de seu livro Die Normen und ihre Übertretung ${ }^{3 !}$, defende que a reparação teria como fator principal a criação do dano. Na segunda edição, a idéia é aperfeiçoada e Binding fala em princípio da causação do dano Verursachungsprinzip - que seria a regra fundamental de todas as obrigações de indenizar. Era o agente que deveria suportar os efeitos do seu ato, bem como dos instrumentos e prepostos de que se serve, e não a vítima. Aí está a origem do princípio da causalidade na responsabilidade civil.

De outro lado, para Binding, a pena constituiria a sanção própria do ilícito, diferindo ontologicamente da reparação. O essencial do ilícito seria a infração a um dever de caráter público pelo qual o indivíduo estaria vinculado ao Estado, devendo responder perante este no caso de seu descumprimento. Decorrência natural de tal liame por meio do dever era de que a culpa fosse parte integrante do delito. Então, a responsabilidade civil poderia dispensar o elemento anímico para se configurar, ao contrário da penal. Assim, o dano seria uma realidade objetiva, o que dispensaria a consideração do elemento subjetivo na sua distribuição.

Logo após Binding, foi o professor bolonhês Venezian que, em uma obra intitulada Danni e resarcimenti fuori del contrattit ${ }^{32}$, sob influência da escola positiva do direito penal, também propôs o despreendimento da responsabilidade civil de quaisquer elementos intencionais. Embora não tenha tido contato com Binding, chegou a conclusões semelhantes sobre o ressarcimento como consequêencia necessária do torto, como uma realidade objetiva social em que um indivíduo lesaria a esfera jurídica de outro. Por isso, quaisquer acontecimentos ordenados a obter uma vantagem, ainda que involuntários, poderiam ser a origem da obrigação de indenizar, como uma forma de remover a causa do dano e restabelecer a ordem jurídica turbada.

Tanto Binding como Venezian formaram concepções causalistas da responsabilidade civil, mas a literatura alemã e austríaca continuou a produzir diversas outras teorias para explicar a emergente responsabilidade objetiva. Marton ${ }^{33}$ considera que das obras produzidas as teorias mais relevantes estariam ligadas aos seguintes princípios: a) interesse ativo, b) prevenção, c) equididade ou interesse preponderante, d) distribuição dos danos, e) Gefahrdung.

a) $\mathrm{O}$ princípio do interesse ativo consistiria em se atribuir o dano àquele que tivesse o benefício decorrente do empreendimento, com uma evidente e convincente ligação ao princípio da justiça distributiva. Dentro de tal perspectiva, quem explora, no seu próprio interesse, uma atividade qualquer deve responsabilizar-se pelas consequiências do empreendimento. Em relação a tal princípio, o professor austríaco Victor Mataja ${ }^{34}$ desenvolveu-o a partir de considerações de ordem econômica. Ele 
considerou que a doutrina tradicional da culpa conduzia a resultados absurdos em relação ao balanço das atividades econômicas.

É que as perdas e os danos decorrentes de acidentes e eventos inevitáveis à exploração de um empreendimento deveriam ser consideradas como custos de exploração, independentemente de atingirem o proprietário ou terceiros. Se o sistema de responsabilidade permite ao empresário repassar tais custos por danos aos terceiros lesados, isso significa falsear o balanço de produtividade do agente econômico, com uma subvenção embutida por parte do prejudicado. Portanto, mostra-se indispensável que esses ônus do empreendimento sejam atribuídos ao seu explorador.

b) O princípio da prevenção revela-se como outra função que a responsabilidade objetiva pode assumir. Ele consiste em estimular ao indivíduo que direcione todos os seus esforços para evitar os danos inerentes à sua atividade. A consciência da atribuição iminente de danos persuade o empreendedor a tomar mais precauções que as usuais, assumindo uma diligência máxima. Ainda que essa diligência não seja máxima o agente será responsável pelo seu resultado.

c) O princípio da equidade, como visto, foi o primeiro fundamento para que a responsabilidade não se fundasse exclusivamente na culpa, a partir da concepção que também os incapazes de discernimento deveriam indenizar os danos por eles causados. Marton ${ }^{35}$, com razão, manifesta estranheza pelo fato de que se tenha aceito nas primeiras codificações jusnaturalistas e no Código Civil suíço essa responsabilidade de menores e alienados, os mais distantes da culpa, mas se recusasse a sua extensão para outros casos de responsabilidade civil. Se é equitativo condenar uma criança a indenizar, com muito mais razão o é um rico capaz que causou um dano, ainda que sem culpa. Não existe, na sua opinião, justificativa para se restringir a equidade somente aos incapazes.

Marton considera que a tese de Adolphe $\mathrm{Merkel}^{36}$ do interesse preponderante seria uma derivação do princípio da equidade, pela qual dever-se-ia sopesar qual seria socialmente o interesse mais relevante a ser preservado para distribuição do ônus da obrigação de indenizar. Em outras palavras, se para a sociedade, no caso concreto, seria mais importante fazer com que o autor do dano suporte o encargo, indenizando o prejudicado ou se seria mais conveniente que o lesionado arque com dano ao seu direito, no momento em que se lhe nega a sua reparação.

d) O princípio da repartição dos danos segundo o qual os ônus decorrentes de um prejuízo deveriam ser suportados por todos aqueles que têm algum interesse na atividade econômica que o causou ou mesmo por toda a coletividade. A idéia é retirar o dano da esfera do indivíduo em que os seus efeitos podem ser devastadores, deslocando-o para uma coletividade, seja de produtores, fabricantes, consumidores, seguradoras, etc. O principal objetivo é que os indivíduos não suportem o encargo do dano, mas que ele seja socializado ou suportado por um sistema de seguros ou de socialização por sua dispersão na cadeia de produção e consumo. 
e) O princípio da Gefahrdung está ligado ao perigo iminente e ameaçador. A palavra Gefahr pode referir-se a um risco inerente a todas as coisas e atividades, ou seja, a um risco normal. No entanto, interessa para a teoria um outro significado da palavra que simboliza um perigo iminente, concreto, anormal e ameaçador que seria o que geraria a responsabilidade pela indenização do dano, obrigando todos aqueles que exerçam tais atividades a evitar prejuízos para terceiros e a repará-los quando ocorrentes.

Essas foram as mais significativas teorias que se desenvolveram na Áustria e Alemanha sobre a responsabilidade civil objetiva, em face das hipóteses já positivadas nas legislações de tais países que prescindiam da culpa para o surgimento da obrigação de indenizar. Todavia, na França e nos países que sofriam a sua influência, somente no final do século XIX, a questão ressurgiria.

Até então os danos eram compostos exclusivamente com base na culpa. A exceção estava apenas em positivações ou albergamento pela jurisprudência de três quase-delitos do direito romano que constituíam hipóteses de responsabilidade indireta (effusum et delectum, positum et suspensum e receptum nautarum, cauponum, stabulariorum) que mesmo assim eram geralmente referidos a hipóteses específicas de culpa como a in vigilância e in eligendo.

Mesmo em tais países ligados à tradição francesa em que não havia nenhuma lei positiva estabelecendo claramente a responsabilidade objetiva, as transformações de vida determinadas pela Revolução Industrial produziram inquietações sociais e revelaram a insuficiência da responsabilidade por culpa para amparar o crescente número de vítimas de acidentes de trabalho. Tomava-se consciência que as máquinas - no sentido literal e figurativo para representar a economia e o Estado - matavam e mutilavam.

Essa realidade social forçou uma releitura dos arts. $1.384,1.385$ e 1.386 do Código Civil Francês. Principalmente com base no art. 1.384 do Código Civil Francês ${ }^{37}$, Laurent ${ }^{38}$ defendeu a tese de que as coisas que se têm sob a guarda deveriam ser consideradas como as inanimadas. A Corte de Cassação Francesa acolheu tal entendimento em junho de 1896 , no qual se decidiu que o proprietário de um rebocador era responsável pela morte de um mecânico. Esse acórdão foi o primeiro passo para a criação da responsabilidade objetiva pela teoria do risco na França. Saleilles e Josserand integraram-se a esse movimento para alargar o âmbito da responsabilidade civil por culpa assim como para levar a responsabilidade além da culpa ${ }^{39}$.

Desde então, é inegável que os fatores objetivos de imputação de responsabilidade vêm ganhando prestígio. Cada nova lei sobre o assunto tende a alargar o campo

37 A redação de tal artigo é a seguinte: art. 1.384. Há responsabilidade não somente pelo dano que se causa por fato próprio, mas também por aquele causado pelo fato das pessoas pelas quais se deve responder ou das coisas que se tem sob sua guarda.

38 In ALSINA (Op. cit., p. 53).

$39 \operatorname{LIMA}(1999$, p. 40) 
de aplicação das hipóteses de responsabilidade objetiva para a composição do dano ${ }^{40}$. Surgiu, ainda, o campo para construção de outros modelos de responsabilidade, centrados em outros aspectos funcionais e valorativos, que não apenas o risco, como é o caso da garantia e da eficiência.

No Brasil, essa tendência ao alargamento, como já dito, fez-se presente a partir da década de 30 do século XX, tendo sido a teoria introduzida especialmente por uma apropriação da doutrina francesa ${ }^{4 !}$, principalmente a partir de Salleiles e Josserand.

\section{2.3 - Os modelos de responsabilidade por eqüidade (objetiva)}

Como já ressaltado, foi Thomasius o precursor da chamada responsabilidade objetiva $^{42}$, quando defendeu que a ação de responsabilidade civil não se ligava mais às fontes romanas por meio do damnun iniuria ou qualquer outro ilícito. Para tanto, destacou o caráter equitativo e meramente ressarcitório do dano de tal ação. O cerne da chamada responsabilidade objetiva está, portanto, na equidade.

Em sentido semelhante, Perelman com muita propriedade chama a atenção para o fato de a origem da teoria do risco estar na própria idéia de equidade que obrigou uma revisão dos critérios de indenização nos acidentes industriais, no século XIX:

Eis alguns exemplos que permitem compreender melhor como o juiz não se contenta em aplicar a regra da justiça, mas se serve de seu poder de interpretação e de apreciação para que suas decisões se conformem ao seu senso de eqüidade.

Outro eminente exemplo de trabalho criativo, em matéria jurisprudêncial, é fornecido pelas sucessivas interpretaçōes do art. 1.382 do Código de Napoleão, que se contenta em afirmar que 'todo e qualquer ato do homem que causa a outrem um dano obriga aquele por, cuja culpa ele ocorreu, a repará-lo.' Através de sucessivas interpretações, a jurisprudência belga e francesa pôde estender $e$ até transformar o sentido dos termos 'causa' $e$

40 A afirmação de Alvino LIMA (1999: 42) sobre o assunto é esclarecedora: $O$ que pretendemos demonstrar, no presente trabalho, é a verdade do conceito de Josserand. A teoria do risco tem conquistado terreno sobre a responsabilidade fundada na culpa, quer na elaboração dos próprios preceitos do direito comum, como em sua interpretação pelos tribunais, quer na legislação especial. resolvendo hipótese que não poderiam, ser, com justiça e equidade, no ambito estreito da culpa. Essa afirmação de Josserand, a despeito de asserções em contrário, está presente confirmada na introdução de vários dispositivos legais, consagrando a responsabilidade objetiva, como veremos, no novo Código Civil italiano, no do México, no projeto de Código Civil da Hungria, nos Códigos das Obrigações da Polónia e do Libano, ao lado de um grande número de leis especiais reguladoras de responsabilidade.

41 Confirmando tal verificação estão Alvino LIMA (Op. cit., p. 39), AGUIAR DIAS (1944, p. 10), MELO DA SILVA (1962, p. 93) e PEREIRA (Op. cit., p. 16).

42 MARTON (1938, p. 156). 
culpa de modo que se imputasse a responsabilidade de um dano não só àquele que cometeu um erro, mas também àquele que deu origem a um risco ${ }^{43}$.

A denominação de responsabilidade objetiva foi, pois, fruto do reducionismo e da incapacidade do positivismo e do neopositivismo de lidarem com a complexidade da atuação humana e com valores. Por isso, achavam estar lidando apenas com fatos naturais ou, mais absurdamente, estarem reduzindo atos humanos a fatos, ao mutilá-los de seus aspectos voluntarísticos.

Ocorre que a própria origem das teorias chamadas objetivas de responsabilidade contraria tal concepção de que se poderia ignorar os aspectos subjetivos. A sua base estava na formulação de teorias como a de risco proveito ou risco criado. Aquele que se aproveitasse dos benefícios de uma atividade deveria ser responsável pelo prejuizo dela advindo, assim como o que iniciasse voluntariamente um processo que gerasse riscos anormais deveria responder por suas conseqüências ainda que imprevisíveis.

Isso demonstra que, para uma adequada distribuição dos danos sociais, jamais foi necessário transformar a intervenção humana no mundo em mero objeto. Muito ao contrário, pois o que ocorre é valorizar a responsabilidade por resultados, como bem acentua Apel:

Pois do que hoje se trata, pela primeira vez na história do homem, é de assumir a responsabilidade solidária pelas conseqüências e subconseqüências em escala mundial das atividades coletivas dos homens - como, por exemplo, a aplicação industrial da ciência e da técnica - e de organizar essa responsabilidade como práxis coletiva. $O$ indivíduo, como destinatário de uma moral consensional, não pode assumir essa tarefa por mais responsável que se sinta; e a alternativa ao burocratismo despótico-totalitarista, que retire do individuo sua co-responsabilidade, não é como ensina a experiência do socialismo de Estado - nem efetivo nem compativel com a liberdade e a autonomia moral do indivíduo ${ }^{44}$.

Não se trata de reduzir a complexidade da vida humana transformando-a em mero objeto de análise, o que sem dúvida alguma é incompatível com a dignidade da pessoa humana e de autonomia. Em verdade, há, em tais modelos de responsabilidade chamados objetivos, a assunção de códigos operacionais e instrumentais para valorizar a responsabilidade por conseqüência e por resultados.

$\mathrm{O}$ risco e a garantia, dentre outros, foram assumidos historicamente pelo direito para possibilitar uma equânime distribuição dos danos na sociedade complexa. A própria vivência do direito levou a que a responsabilidade, pelo menos em relação à reparação, estivesse cada vez mais próxima dos resultados do que da própria 
conduta. Em verdade, jamais se tratou de ignorar a vontade e o livre-arbitrio, mas sim de alargá-los para abranger as modificações cada vez mais complexas da intervenção humana. A autonomia ética, na sociedade complexa, não se resume ao controle da própria conduta, mas principalmente das consequiências sociais desta.

Portanto, não há qualquer sentido em falar-se de responsabilidade objetiva, reduzindo o sentido do dever e da ação humana sobre o mundo. A melhor denominação que corresponde inclusive às origens da idéia é a de responsabilidade por equiidade, já que se está cuidando da equânime distribuição de riquezas numa sociedade complexa a partir de sentidos deontológicos que enfatizam os resultados da intervenção do homem na natureza e na sociedade.

O sentido deontológico constituído a partir de tais códigos e avaliações típicos do risco, da garantia e da eficiência assinalam critérios de distribuição de custos na sociedade complexa. Não se reprova o industrial por haver colocado produtos defeituosos no mercado, quando ele não poderia ter ciência de tal fato, o que se faz é atribuir-lhe os ônus daí resultantes. A contingência do risco revela-se inerente a várias atividades na sociedade e não há qualquer interesse em proibi-las. O que se objetiva são providências para minimizar os riscos e nas hipóteses que eles sejam inevitáveis que quem voluntariamente os criou ou deles tenha tirado um benefício suporte as suas consequiências.

Isso se dá com a própria alteração dos custos da atividade e de sua distribuição. A responsabilidade por equidade obriga a que o empreendedor da atividade altere $o$ seu comportamento, seja assumindo medidas preventivas para evitar os custos dos danos, seja mesmo diminuindo a atividade que os gera. É que os encargos advindos da indenização das vítimas passam a ser uma preocupação importante para a manutenção da atividade ${ }^{45}$.

Outra característica é a de que, em se tratando de uma atividade produtiva, os custos dos acidentes acabarão sendo repartidos por todos os que têm interesse na sua manutenção, sejam os próprios produtores ou mesmo os consumidores por meio da transferência de custos pelos preços. Os danos passam a ser então repartidos socialmente, não sendo suportados exclusivamente pela vítima.

A partir de tais códigos operacionais, a responsabilidade como instituto jurídico atua muito próxima da lógica do sistema econômico, gerando resultados preventivos por meio da ampliação da sanções restitutivas, assim como abarca todos os envolvidos no processo econômico, com multiplicidade de produtores e consumidores que formam uma cadeia de produção e consumo ${ }^{46}$.

A configuração do dever a partir do modelo do ato ilícito e, conseqüentemente, a imputação de responsabilidade subjetiva estão ligados necessariamente à conduta humana. Em outras palavras, haverá sempre a indagação se era possível ao causador do dano evitá-lo, se poderia ter agido de forma a afastá-lo, pois é esse o cerne da culpa. Em contraste, o dever na responsabilidade por eqüidade surge inde-

45 STEINER (1987, p. 63).

46 Os efeitos econômicos desse tipo de responsabilização, bem como de outras estão analisados nos capítulos 6 e 7 de POSNER (1998, pp. 179-270), bem como o capítulo IV e V de SCHÄFER \& OTT (1991, pp. 98-217). 
pendentemente da indagação se seria possível ao sujeito responsável evitá-lo. Pressupõe-se que aquele que voluntariamente cria um risco assume a posição de garantir ou está em uma posição de eficiência e tem o dever de evitar o dano e de assegurar a terceiros em face das atividades pelas quais se é responsável.

$\mathrm{Na}$ responsabilidade por eqüidade, exige-se um compromisso com os resultados, de modo que, se o dano não pode ser evitado concretamente, ele deve ser reparado. $O$ intuito é resguardar o interesse da vítima que, geralmente, nas circunstâncias de tal modelo de responsabilidade estará em uma posição de desvantagem em relação ao responsável pelo dano no que concerne ao controle dos resultados e mesmo para suportar os ônus do dano. Por isso, caso não seja possível a este último evitar o dano, ainda assim surgirá o dever de indenizar, a partir dos códigos e modelos do risco, da garantia, da eficiência e da própria eqüidade.

\section{III. $2.4-O$ modelo de responsabilidade por eqüidade com base no risco}

Apesar de os modelos de responsabilidade por eqüidade, comumente chamados objetivos, apoiarem-se em outras avaliações que não apenas o risco, no presente estudo, apenas este será abordado, em razão de ser o mais largamente estudado e utilizado. Isso se explica por ser uma das tônicas da sociedade contemporânea a organização e minimização de riscos.

\section{2.4. $l$ - Noção sobre o risco}

A própria etmologia da palavra risco remete à transição da Idade Média para a Idade Moderna. A palavra emergiu no catalão do século XIV, tendo se espraiado para as línguas latinas no século XVI e para as anglo-saxônicas no século XVII. O vocábulo destinava-se a falar da possibilidade de ocorrência de eventos vindouros, em um momento histórico onde o futuro passava a ser pensado como passivel de controle ${ }^{47}$.

As navegações empreendidas em tal período eram um exemplo do contexto do uso de tal palavra. $O$ conhecimento náutico de então não excluía os perigos do empreendimento, mas o tomava dominável. A idéia de risco conectava-se à compreensão de que resultados inesperados podem ser uma conseqüência de nossas próprias atividades ou decisões ${ }^{48}$.

Assinala-se uma transformação na visão de mundo em que, em períodos anteriores, era encarado como destino ou fortuna. $O$ risco indica a substituição do ator principal do enredo social. $O$ insucesso, o perigo e as frustrações deixam de ser cosmológicos ou teológicos. É a partir da Idade Moderna que as contingências que afeiam a humanidade passam a ser atribuídas ao próprio homem.

47 SPINK, Mary Jane P. Trópicos do discurso sobre risco: risco-aventura como metafora na modernidade tardia. p. 1.279 In www.scielo.br/pdf/csp/vl7n6/6944.pdf - acesso em 17.09.2004 48 GIDDENS (1991:38). 
O risco, sem dúvida alguma, pressupõe o insucesso, o perigo e a frustração. Todavia, a partir da noção de risco, as decepções passam a ser objeto de cálculo e previsões racionais. $O$ perigo não está fora das navegações, da comenda ${ }^{49}$ ou da empresa. Aliás, essas três realidades só existem por pressuporem o perigo e 0 desconhecido. Todavia, mesmo o inesperado deve ser objeto de cálculo. $\mathrm{O}$ risco insere-se na modernidade como uma forma do homem relacionar-se com o futuro que pressupõe cálculo e gestões.

Não é, por acaso, que essa perspectiva de tempo relacionada ao risco, vincule-se aos marcos da história do capitalismo. E o aprofundamento da organização racional do trabalho iniciada na Idade Média que permite os grandes empreendimentos. $\mathrm{O}$ risco conecta-se ao homem da técnica, do cálculo econômico e da mecânica social. O seu avanço é o mesmo da idéia de batalha metódica contra a natureza na sociedade moderna em que essa luta, junto à primazia outorgada ao cálculo e à eficácia, tende a converter-se no sagrado desse tempo ${ }^{50}$.

A significação social do risco também caminha com as formas e o instrumental de objetivação e de universalização da modernidade. A matemática que já havia ressurgido na Idade Média com as artes liberais, na modernidade no século XVII, forma heróis como Pascal, Fermat, Leibniz e De Moivre. E a partir daí que se desenvolve o cálculo de probabilidade. Nos séculos seguintes, desenvolve-se a estatística que encontra uma primeira aplicação no governo dos estados germânicos - século XVIII e XIX ${ }^{51}$. A probabilidade e a estatística potencializam os campos de aplicação da noção de riscos.

Todavia, é, com o Estado de Bem Estar Social, não por acaso contemporâneo ao grande avanço da teoria da probabilidade com Keynes ${ }^{52}$ que a gestão dos riscos ganha dimensão social central. Só é possível fornecer bens e serviços para a sociedade por meio de um sofisticado planejamento que se vale de todo o instrumental legado pelas ciências.

O passo seguinte, o próprio esgotamento do Estado de Bem-Estar Social, é novamente marcado por uma nova expansão do risco. A partir da verificação que a ação do Estado não é capaz de gerir todos os riscos sociais é que surgem outros conceitos como, por exemplo, risco ambiental e risco global.

Foi, em face dessa noção de risco, que envolve uma perspectiva de futuro em que o homem deve passar a fazer cálculos, previsões e gerir a suas atividades e seus efeitos que se desenvolveu a teoria jurídica que atribui a responsabilidade com base no risco.

49 A comenda era, nos primórdios do comércio medieval, uma operação de crédito do comerciante marítimo em que o capitalista afiançava dinheiro a um mercador em vista de participação direta nas utilidades que este último houvesse angariado numa expedição comercial além mar. GALGANO $(2001$, p. 44).

50 RICOEUR (2002, p. 393).

51 SPINK, Mary Jane P. Trópicos do discurso sobre risco: risco-aventura como metáfora na modernidade tardia. p. 1.279 In www.scielo.br/pdf/csp/v17n6/6944.pdf- acesso em 17.09.2004.

52 Sobre o assunto, FEIJÓ (2001, pp. 427-8). 


\section{2.4.2 - A teoria do risco e a dignidade da pessoa humana}

Antes de mais nada, analisar as relações entre teoria do risco e dignidade da pessoa humana exige a superação de um mal entendido derivado de compreensões reducionistas vinculadas às teorias da responsabilidade objetiva. Adotar a teoria do risco não está de forma alguma vinculada a uma atribuição de responsabilidade por fatos ou por meros atos-fatos como já defendeu Pontes de Miranda ${ }^{53}$. Muito menos equivale, a expurgar todos os aspectos voluntarísticos e anímicos ${ }^{54}$ na atribuição da responsabilidade, enfocando-se apenas três elementos: o dano, o ato e o nexo de causalidade entre os dois. Essas duas abordagens não correspondem ao significado que se atribui ao risco e a teoria jurídica de responsabilidade com base no risco.

Nada melhor para avançar sobre tais dificuldades do que retomar para o mais significativo marco da introdução da teoria do risco no Brasil: os estudos de Saleilles sobre a responsabilidade civil nos acidentes de trabalho. Saleilles, em artigo publicado no final do século XIX, chamou a atenção para as dificuldades advindas da responsabilidade por acidentes laborais. É que, em realidade, a causa imediata e aparente provinha de um fato relacionado com a vítima, como, por exemplo, um movimento em falso que a faz ficar presa em uma máquina. Para provar a culpa do patrão, seria necessário ir mais longe, imputando-se-lhe quase sempre uma omissão por não haver tomado os cuidados necessários para evitar o dano.

Surgem, então para ele, duas questões a examinar. Se trata de omissão, a precaução omitida seria um dever do patrão. Quais seriam, assim, as precauções que lhe seriam impostas? De outro lado, como estabelecer o nexo de causalidade entre a omissão verificada e o acidente superveniente?

À primeira pergunta, a jurisprudência francesa da época do artigo impunha progressivamente exigências mais severas de precaução, exigindo cuidados extraordinários por parte do patrão para excluir a sua responsabilidade.

Em relação à segunda, os arestos consideraram que a relação de causalidade estabelecer-se-ia pelo fato de que, se o patrão tivesse tomado as precauções necessárias, o acidente não ocorreria. Acontece que, diante do crescente alargamento dessa nova jurisprudência, essa interpretação mostrava-se cada vez mais insuficiente. Diante de um fato espontâneo da própria vítima, como provar que mesmo com as precauções necessárias o evento não teria ocorrido? Nesse sentido, uma decisão estabelecia a responsabilidade do empregador pelo simples fato de ter contratado três jovens para lidar com uma máquina que habitualmente prendia mãos. No entanto, qualquer um poderia ter sido vítima desse acidente independentemente da idade. Outro precedente referia-se à pouca luz do estabelecimento para imputar a responsabilidade por um movimento em falso do empregado que lhe causou um acidente. Para Saleilles, havia em todos esses casos o risco profissional, já que os próprios precedentes não afirmavam com certeza que as medidas exigidas poderiam ter

53 PONTES DE MIRANDA (1954, t. II, p. 198).

54 Como defendido por Binding e Venezian - item III.2.2. 
evitado os eventos danosos. Em verdade, é uma questão de risco que se coloca como encargo do paträo ${ }^{55}$.

Dentro da sistemática do art. 1.382 do Código Civil Francês, a responsabilidade por ato ilícito, delitos e quase-delitos, estaria fundada sobre um ato voluntário diretamente ligado a um dano realizado. Era uma relação de causa e efeito que fundamentava a responsabilidade. No entanto, após a evolução da jurisprudência, esta relaçāo de causa e efeito tende a se desarticular ${ }^{56}$. É a culpa, entendida como um ato voluntário, que se tem em vista, menos na sua relação subjetiva com o acidente ou como vontade imprudente, desatenta, mas sobretudo na sua materialidade e nos seus elementos objetivos ${ }^{57}$. Para Saleilles, trata-se em síntese de uma culpa objetiva, ou seja, contanto que se caracterize o ato como voluntário, o que interessa são os seus elementos materiais.

Então, não se pode dizer que haja culpa do patrão como causa do acidente, mas se verifica um ato irregular que se imputa ao patrão, ao colocar os riscos como seu encargo. Não há causalidade direta, mas um ato voluntário a partir do qual se atribuem os riscos ao empregador.

No direito francês, o fundamento positivo para tal teoria foi encontrado na responsabilidade pelo fato das coisas do art. 1.384 do Código Civil. Esse dispositivo se refere à idéia de guarda, isto é, em seu interesse e proveito assumir a vigilância $e$ os riscos em seguida: nada mais justo ${ }^{58}$. Em razão das coisas que se utilizam para trabalhar sob a direção e o proveito do empregador, é que os acidentes podem ocorrer. Por isso, aquele que tem aproveito suporta os riscos ${ }^{39}$.

Para Salleiles, já estava clara a idéia de que a responsabilidade civil não poderia mais ficar restrita a relações de causa e efeito. De outro lado, também não se poderiam imputar quaisquer fatos danosos aos patrões e empresários. Era necessária uma relação subjetiva que legitimasse a imposição da sanção restitutiva. Daí a importância da assunção voluntária dos negócios e de seus riscos inerentes. Para Salleiles, o agente que tirasse voluntariamente proveito de um negócio deveria suportar seus riscos. A teoria do risco tal como concebida por Salleiles afastava-se completamente da causalidade, buscando o sentido da imputação em um aspecto subjetivo: a assunção voluntária dos proveitos de um empreendimento, que necessariamente deveria comportar os seus riscos.

Está aí a idéia central da teoria do risco que de forma alguma é incompatível com a análise de questões voluntarísticas. Em verdade, as pressupõe. Só que, ao contrário da responsabilidade por ato - subjetiva - o que define a responsabilidade não são aspectos voluntarísticos concernentes à conduta, mas ao risco.

Em outras palavras, quem se coloca voluntariamente no desempenho de uma atividade que pressuponha o cálculo de risco deve suportar todos os perigos que lhe são inerentes, ainda que estes estejam além de sua capacidade de gestão. Quem

55 SALEILLES $(2001$, p. 20).

56 Idem. Ibidem, p. 22.

57 Idem. Ibidem.

58 Idem. Ibidem, p. 25.

59 Idem. Ibidem, p. 26. 
assume o risco deve suportar todas as suas consequiências. Aí está a espinha dorsal da teoria do risco.

A retomada das lições de Josserand no seu célebre De la Responsabilité du Fait des Inanimées reforça a necessidade da assunção dos perigos criados voluntariamente. Daí Josserand considere que o caso fortuito deve ser colocado a cargo daquele que o determinou, provocou e não daquele que somente foi vitimado por ele $e^{60}$. Todavia, Josserand salienta, com propriedade, que a responsabilidade não é por risco da humanidade, mas sim por risco criado. Por isso, o proprietário de uma coisa deve responder por caso fortuito, mas jamais por força maior ${ }^{61}$.

Para Josserand, os danos, no caso fortuito, adviriam diretamente da coisa, enquanto a força maior proviria de fatos absolutamente independentes. No caso de uma empresa, os primeiros seriam determinados em seu interior, dentro de seu domínio; e os segundos teriam origem externa, fora de seu controle. A força maior está totalmente excluída como origem de responsabilidade por dano, já que o proprietário da empresa ou da coisa não poderia exercer nenhuma influência, sobre os elementos naturais, a guerra, a violência organizada sobre esses eventos que a lei inglesa reúne sob a expressão 'fatos de Deus ou dos inimigos da Rainha'62.

Nesse sentido, Savatier ${ }^{63}$, para ressaltar a limitação da idéia de risco, ressalta que já em 2 de dezembro de 1941, as Câmaras reunidas da Corte de Cassação Francesa unificaram jurisprudência declarando que o proprietário de um automóvel roubado não poderia ser considerado como responsável por um carro que circule sem a sua concordância e contra a sua vontade. Assim, deve haver ao menos um vínculo subjetivo com a atividade à qual o risco seja inerente para que surja a obrigação de indenizar. Está aí um exemplo concreto da inadequação da visão objetivista do risco.

A teoria do risco não significa de modo algum a mera responsabilidade por acontecimentos, totalmente desvinculada de qualquer nexo voluntário. Ela é apenas a superação dos estritos limites da responsabilidade por ato em que se atribui a sanção a alguém com vistas ao passado.

O surgimento da noção de risco acompanhou uma mudança de perspectiva temporal em que as atividades humanas projetaram-se acentuadamente para o planejamento e a gestão do futuro. Se a economia, o Estado e a própria sociedade já haviam deslocado seus olhos para um horizonte abstraio e prospectivo, o direito também acabou por assumir a mesma postura na atribuição dos eventos danosos na sociedade.

Se alguém desenvolve uma atividade calculando os riscos de seus prejuízos, de modo a geri-los racionalmente, também está apto a suportar os danos que gere para terceiros. A teoria do risco simplesmente adota a mesma abordagem utilitária, instrumental e preventiva das atividades que se desenvolvem mediante as complexas técnicas de intervenção e domínio no mundo da contemporaneidade. Se todo esse aparato potencializa a capacidade de intervenção humana no mundo, também a responsabilidade deve acompanhá-la.

61 Idem. Ibidem, p. 122.

62 Idem. Ibidem, p. 123.

63 SAVATIER (1950, p. 150). 
Em tal modelo, busca-se proteger e resguardar os interesses de potenciais vítima de danos surgidos de atividades perigosas exercidas a partir de uma organização e um domínio complexo da técnica. Como na sociedade nem todos os atores têm o mesmo acesso a esse instrumental, é certo que haverá pessoas desprotegidas e vulneráveis. Obviamente quem dispõe de meios sofisticados e elaborados de intervenção no mundo dispõe de maiores possibilidades de atuar, ou seja, mais liberdade e autonomia. Sem dúvida, os bens estão distribuídos de forma desigual na sociedade.

E para evitar que essa alocação heterogênea coloque em cheque as chances de sobrevivência dos hipossuficientes que se adota a teoria do risco. Foi o que ocorreu com os acidentes de trabalho. Se ao empregador não fosse imputado o ônus de fazer frente ao infortúnio de seus empregados, a subsistência destes seria incerta. A adoção da teoria jurídica do risco visa a recompor tal desequilíbrio de possibilidade, procurando o resguardar o mínimo de dignidade e autonomia material dos indivíduos.

A teoria do risco surgiu durante a crise do modelo de estado liberal em que a liberdade e a autonomia eram enfocados primordialmente sob um aspecto formal. Os próprios acidentes de trabalho demonstraram que a liberdade e a autonomia não podem ser efetivamente exercidas apenas a partir de garantias formais. A razão de se condenar o empregador era o reconhecimento de um desnivel material entre os envolvidos. $\mathrm{O}$ alargamento dos pressupostos visou sobretudo a resguardar a dignidade dos trabalhadores sob um ponto de vista substancial.

A adoção da teoria do risco, portanto, mostra-se como forma de possibilitar a distribuição equânime dos ônus sociais. A teoria do risco apresenta variantes conforme critérios orientadores da equidade. Assim se fala em risco proveito, em risco criado, em risco da empresa, em risco profissional, etc. Quaisquer que sejam esses critérios de atribuição de riscos, todos eles exigem a assunção voluntária da atividade que potencialmente pode gerar o risco e os danos dela decorrentes. Como Josserand já afirmava, não se trata de atribuir a alguém a responsabilidade por todos os riscos da humanidade, mas somente o risco que a pessoa criou, ou do qual ela retira benefícios, bem como os inerentes ao empreendimento ou ao exercício da profissão.

Há, portanto, uma análise da capacidade de livre entendimento e manifestação de vontade de quem tenha o domínio da atividade, mas o seu foco não é o ato e sim o risco. De modo algum, a teoria do risco significa uma objetivação absoluta da responsabilidade. Em verdade, ela é o reconhecimento de que, se o empregador, o empresário e o Estado têm maiores possibilidades materiais de ação, por conseqüência, devem ter maiores responsabilidades. Não se pode esquecer que autonomia significa responsabilidade. Então, se há maior autonomia, deve haver maior responsabilidade.

\section{IV - Considerações finais}

A dignidade da pessoa humana, como princípio jurídico fundamental, certamente espraia-se por todo o direito civil, inclusive pela responsabilidade. Tal concepção ocupou o centro da formação do direito moderno pela escola do direito racional e acabou sendo absorvida pelas escolas de influência positivista que as sucederam. Por isso, desdobramentos da dignidade da pessoa humana são elementos chaves para a compreensão dos diversos modelos de responsabilidade civil. 
A partir das lições de Kant, pode-se dizer que a idéia central da dignidade da pessoa humana é a de considerar o homem universalmente, em função de sua autonomia, como um fim em si mesmo e por isso como um valor sem equivalente e inapreciável. Por ser dotado de autonomia, o indivíduo é capaz de conhecer os seus deveres e de dirigir suas ações pela vontade, conformando-as a uma ordem superior e obrigatória - ordenamento jurídico, respondendo pelos seus fracassos. É porque todas as pessoas são dotadas de autonomia e capacidade de autodireção a um conteúdo de sentido obrigatório que qualquer sanção só pode ser legitimamente imposta a partir da valoração da vontade e da consciência.

O Novo Código Civil positiva duas grandes vertentes de modelos de responsabilidade: por ato ilícito (subjetiva) e por eqüidade (objetiva). A imputação de responsabilidade com base no ato ilícito vincula-se à concepção judaico-cristã de pecado, em que o ato é julgado a partir de deveres oriundos de uma ordem superior de sentido. De outro lado, os modelos de eqüidade, principalmente o do risco, relacionam-se à Revolução Industrial e à consolidação do Estado-nação no século XIX. Em tal período, cresceu vertiginosamente a intervenção do homem na natureza e acentuou-se a perspectiva de futuro com cálculos e gestões de riscos. A partir de tal transformação social, os limites do ato eram demasiadamente estreitos para a responsabilidade civil, o que fez com que também a imposição de sanções restitutivas assumisse o código do risco ${ }^{64}$.

64 A seguinte tabela contém uma síntese da distinção entre responsabilidade por ato ilícito (subjetiva) e a responsabilidade por equidade (objetiva) com a explicitação da relação de ambas com a dignidade da pessoa humana:

\begin{tabular}{|c|c|c|}
\hline $\begin{array}{l}\text { Modelo de } \\
\text { responsabilidade }\end{array}$ & Ato ilícito (subjetiva) & Eqüidade (objetiva) \\
\hline $\begin{array}{l}\text { Códigos (ou juízos } \\
\text { a partir dos quais } \\
\text { se imposta a res- } \\
\text { ponsabilidade) }\end{array}$ & Antijurídico ilícito/culpável. & Risco/garantia/eficiência. \\
\hline $\begin{array}{l}\text { Natureza dos juí- } \\
\text { zos }\end{array}$ & $\begin{array}{l}\text { Juízos são éticos ou morais (moral de } \\
\text { intenção). }\end{array}$ & Juizes são operacionais e instrumentais. \\
\hline Foco Central & $\begin{array}{l}\text { Ato, ainda que se chegue ao resulta- } \\
\text { do. }\end{array}$ & $\begin{array}{l}\text { Resultado da intervenção humana no mun- } \\
\text { do. }\end{array}$ \\
\hline $\begin{array}{l}\text { Posição dos sujei- } \\
\text { tos }\end{array}$ & $\begin{array}{l}\text { Horizontal, havendo igualdade for- } \\
\text { mal e material entre os envolvidos. }\end{array}$ & $\begin{array}{l}\text { Vertical, havendo desigualdade material } \\
\text { em relação ao dano, caracterizando uma } \\
\text { das partes como hipossuficiente. }\end{array}$ \\
\hline $\begin{array}{l}\text { Efeitos em relação } \\
\text { à dignidade da pes- } \\
\text { soa humana }\end{array}$ & $\begin{array}{l}\text { Por ter ínsito um juízo de reprovação } \\
\text { de um ato preocupa-se fortemente } \\
\text { com a dignidade do lesante e da víti- } \\
\text { ma ao analisar aspectos subjetivos da } \\
\text { conduta. }\end{array}$ & $\begin{array}{l}\text { Privilegia a posição da vítima como forma } \\
\text { de manter a sua dignidade na sociedade com- } \\
\text { plexa. No entanto, para não ofender a digni- } \\
\text { dade do ofensor exige um elemento volun- } \\
\text { tário na assunção da atividade que gere o } \\
\text { risco, a garantia ou a eficiência. }\end{array}$ \\
\hline $\begin{array}{l}\text { Perspectiva tempo- } \\
\text { ral }\end{array}$ & $\begin{array}{l}\text { Estabiliza contrafaticamente de ex- } \\
\text { pectativas a partir do passado por ter } \\
\text { como pressuposto a avaliação de um } \\
\text { ato já acontecido. }\end{array}$ & $\begin{array}{l}\text { Estabiliza contrafaticamente expectativas } \\
\text { com vistas ao futuro, pois se preocupa em } \\
\text { distribuir os danos de forma a manter os } \\
\text { diferentes papéis da sociedade complexa. }\end{array}$ \\
\hline
\end{tabular}


A qualificação de um ato como ilícito ocorre a partir de uma avaliação de conduta em que interessa a avaliação da intenção dos atos externalizados. Por isso, a sanção, no modelo do ato ilícito, é decorrência imediata de um juízo de reprovação de uma conduta, consistente na culpabilidade. Só quem tenha capacidade de entendimento e livre manifestação de vontade é que sofrer coerção por ato ilícito. Apenas aquele que tinha autonomia para cumprir seus deveres pode ser responsabilizado com uma sanção.

É dessa forma que se respeita a dignidade do lesante, evitando que o prejudicado o transforme em um meio para o seu enriquecimento. A vítima e o autor do dano encontram-se em posição horizontal de igualdade formal, de modo que será responsável o culpado, ou seja, àquele que tenha cometido, no passado, um erro perante a ordem jurídica.

O modelo de responsabilidade por eqüidade, por sua vez, em virtude da disparidade da capacidade de ação e intervenção das partes, destina-se a distribuir os eventos danosos sociais de forma equânime. Essa idéia pode ser melhor compreendida a partir da teoria do risco, em que a responsabilidade pelos danos se imputa àquele que voluntariamente criou, tira proveito ou tem a capacidade de direção do empreendimento que põe em risco bens de terceiros. Assim, quem tira proveito ou dirige uma atividade que expõe terceiros a um perigo socialmente relevante deve ser responsabilizado pelos resultados relacionados à sua intervenção. É que, se no domínio e controle da natureza, o homem é capaz de calcular riscos, de modo a planejar e gerir o seu futuro, também no âmbito da responsabilidade devem ser-lhe imputados todos os eventos danosos que se vinculem a tal cálculo.

A possibilidade de uns dos envolvidos poder calcular os riscos de sua atividade coloca-o em posição de superioridade material em relação a outra parte. Com isso, há, na teoria do risco, um posicionamento vertical das partes, em que o lesante por ter suas possibilidades de ação potencializadas também tem sua responsabilidade alargada. Se, concretamente, quem dirige o empreendimento encontra-se em posição de maior autonomia, também está em posição de maior responsabilidade. A teoria do risco, dessa forma, corrige a disparidade material existente entre os envolvidos, protegendo a vítima para resguardar a sua dignidade.

De tal modo, a dignidade da pessoa humana estrutura todos os modelos de responsabilidade civil. No ato ilícito, a responsabilidade é imputada àquele que, podendo ter dirigido sua ação conforme ao dever não o fez e, por isso, é culpável. Já, nos modelos por eqüidade, entre os quais o do risco é o principal, a responsabilidade é imputada àquele que, em razão de estruturação de sua atividade, é capaz de gerir os riscos. Está, desse modo, em posição de superioridade material em relação às vítimas, o que faz com que todos os resultados danosos derivados de seu empreendimento lhe sejam atribuídos.

\section{Obras consultadas}

AGUIAR DIAS, José. Da Responsabilidade Civil. Vol. I. Rio de Janeiro, 1944. ALSINA, Jorge Bustamante. Teoria de la Responsabilidad Civil. $9^{\mathrm{a}}$ ed. rev. Buenos Aires: Abeledo-Perrot, 1997. 
APEL, Karl-Otto. Teoria de la Verdad y Ética del Discurso. Trad. Norberto Smilg. Barcelona: Paidós Ibérica, 1998.

CARVALHO NETO, Menelick. A hermenêutica constitucional sob o paradigma do Estado Democrático de Direito. In: Notícia do Direito Brasileiro - Universidade de Brasília - Faculdade de Direito. Brasília, n 6, 2000, p. 233-250.

ESPÍNOLA, Eduardo. Tratado de Direito Civil. Vol. I. Rio de Janeiro: Freitas Bastos, 1939.

FEIJÓ, Ricardo. História do Pensamento Econômico. São Paulo: Atlas, 2001.

GALGANO, Francesco. Lex mercatoria. Bolonha: II Mulino, 2001.

GIDDENS, Anthony. As conseqüências da modernidade. Trad. Raul Fiker. São Paulo: Editora UNESP, 1991.

GRÓCIO, Hugo. Do Direito da Guerra e da Paz. Trad. Jaime Torrubiano Ripoll. Madri: Editorial Réus, 1925.

HOBBES, Thomas. Leviatã. Trad. Alex Martins. São Paulo: Martin Claret, 2002.

JOSSERAND, Louis. De la Responsabilité du Fait des Inanimées. Paris: Arthur Rousseau Éditeur, 1897.

KANT, Emmanuel. Doutrina do Direito. Trad. Edson Bini. São Paulo: Ícone, 1993. . Fondazione delia Metafísica del Costumi. Trad. Pietro Chiodi. Roma: Laterza, 1980.

MARTON, G. Les Fondements de la Responsabilité Civile. Paris: Librairie du Recueil Sirey, 1938.

MELO DA SILVA, Wilson. Responsabilidade sem Culpa e Socialização do Risco. Belo Horizonte: Bernardo Álvares, 1962.

MOREIRA ALVES, José Carlos. Direito Romano. Vol. I e II. Rio de Janeiro: Forense, 2002.

- A Responsabilidade Extracontratual e seu Fundamento: Culpa e Nexo de Causalidade. In: MARTINS, Ives Gandra da Silva (org.). Estudos em Homenagem a Oscar Dias Corrêa. Rio de Janeiro: Forense Universitária, 2001, pp. 187-207.

MUÑOZ CONDE, Francisco \& BITENCOURT, Cezar Roberto. Teoria Geral do Delito. São Paulo: Saraiva, 2000.

PEREIRA, Caio Mário da Silva. Responsabilidade Civil. $9^{\mathrm{a}}$ ed. rev. Rio de Janeiro: Forense, 2001.

PERELMAN, Chaïn. Ética e Direito. Trad. Maria Ermitina Galvão. São Paulo: Martins Fontes, 2000.

POSNER, Richard A. Economic Analysis of Law. $5^{\text {a }}$ ed. Nova Iorque: Aspen Law \& Business, 1998.

RAWLS, John. Leciones sobre la Historia de la Filosofia Moral. Trad. Andrés de Francisco. Barcelona: Ediciones Paidós Ibérica, 1997. 2000.

O Liberalismo Político. Trad. Dinah de Abreu Azevedo. São Paulo: Ática,

RICOEUR, Paul. Del texto a la acción - ensayos de hermêutica II. Trad. Pablo

Corona. México, Fondo de Cultura Econômica, 2002.

ROTONDI, Giovanni. Scritti Giuridici. Milão, Uirico Hoepli, 1922. 
SAVATIER, Rene. Du Droit Civil au Droit Public a Travers les Personnes, les Biens e la Responsabilité Civil. Paris: Librairie Genérale de Droit et de Jurisprudence, 1950.

SALEILlES, R.. Note Sou Civ., 16 Mn 1896. In CARVAL, Suzanne. La Construction de la Responsabilité Civile. Paris: Presses Universitairies de France, 2001. SCHÄFER, Hans-Bernd \& OTT, Claus. Manual de Analisis Econômico del Derecho Civil. Trad. Macarena von Carstenn-Lichterfelde. Madri: Editorial Tecnos, 1991. SOUZA DINIZ. Código Civil Alemão - Traduzido. Rio de Janeiro: Record, 1960. . Código Civil Italiano - Traduzido. Rio de Janeiro: Record, 1961. . Código Napoleão ou Código Civil dos Franceses - Traduzido. Rio de Janeiro: Record, 1962.

. Código Civil Suiço e Código Federal Suiço das Obrigações. Rio de Janeiro: Record, 1962.

SOUSA SANTOS, Boaventura. A Crítica da Razão Indolente. Contra o Desperdício da Experiência. São Paulo: Cortez, 2001.

SPINK, Mary Jane P. Trópicos do discurso sobre risco: risco-aventura como metáfora na modernidade tardia. In www.scielo.br/pdf/csp/v17n6/6944.pdf — acesso em 17.09.2004.

STEINER, Henry J. Moral Argument and Social Vision in the Courts - a Study of Tort Accident Law. Madison (Wisconsin): The University of Wisconsin Press, 1987.

WEBER, Max. Economia e sociedade. Brasília: UnB, 2000.

WELZEL, Hans. Introduccion a la Filosofia del Derecho. Madri:Aguilar 1977.

A dogmática no direito penal. In: Revista de Direito Penal - ns. 13 e 14 Ed., São Paulo: Revista dos Tribunais, 1974, pp. 7 a 12. . O Novo Sistema Jurídico-penal: uma Introdução à Doutrina da Ação Finalista. Trad. Luiz Regis Prado. São Paulo: Revista dos Tribunais, 2001.

WIEACKER, Franz. Historia del derecho privado de la Edad Moderna. Trad. Francisco Fernández Jardón. Madri: Aguilar, 1957. 


\title{
Curso de Prática Forense Cível e Comercial
}

\author{
José de Souza Gama
}

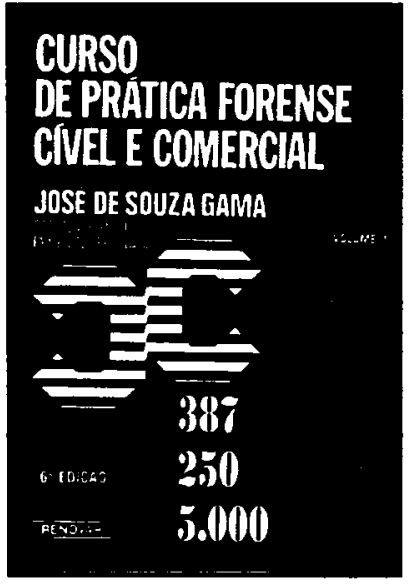

O leitor encontrará nesta obra vinte capítulos didaticamente dispostos, objetivando facilitar o ensino do professor e a aprendizagem do alunado. Cada capítulo é composto basicamente de texto legal, da hipótese (modelo), da jurisprudência e dos exercícios. Seguindo a estrutura do vigente Código de Processo Civil, será encontrada uma série de exercícios que se referem aos casos diários do advogado, e, ao praticá-los, estará aprendendo.

$\begin{array}{lll}\text { Ref. } 0040 & \text { Cartonado } & 2 \text { vols. } \\ 1.692 \text { págs. } & \text { Form. } 16 \times 23 & 1996-6^{\mathbf{a}} \text { ed. }\end{array}$

\section{Curso de Prática Forense Penal}

José de Souza Gama

Esta obra tem como objetivos básicos facilitar o ensino, a aprendizagem e prática, usando o método "Aprenda fazendo". Os exercícios sāo criativos, variados, estimulantes, e a maior parte já foi testada em sala de aula, com excelente resultado. A obra segue rigorosamente a ordem estabelecida no vigente Código de Processo Penal.

Ref. 0026

Form. 16x23
Cartonado 1999
950 págs. $13^{\mathrm{a}} \mathrm{ed}$.

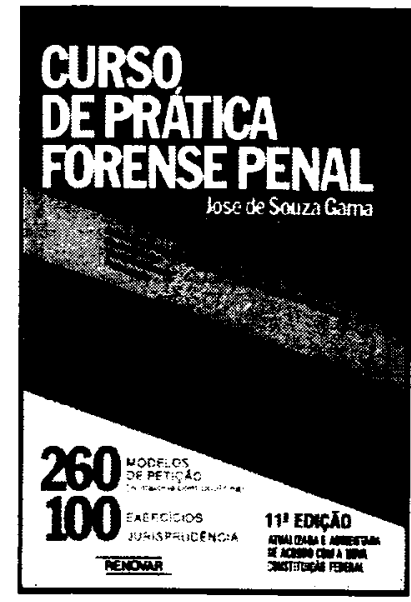

